Canadian

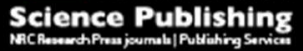

Botany

Botanique

\title{
Rariglanda jerseyensis a new ericalean fossil flower from the Late Cretaceous of New Jersey
}

\begin{tabular}{|r|l|}
\hline Journal: & Botany \\
\hline Manuscript ID & cjb-2016-0062.R1 \\
\hline Manuscript Type: & Article \\
\hline Date Submitted by the Author: & $17-$ Apr-2016 \\
\hline Complete List of Authors: & $\begin{array}{l}\text { Martínez, Camila; Cornell University, Plant Biology Section, School of } \\
\text { Integrative Plant Science } \\
\text { Choo, Thereis; Cornell University, Section of Plant Biology, } 412 \text { Mann } \\
\text { Library, School of Integrative Plant Science } \\
\text { Allevato, Daniella; Cornell University, Section of Plant Biology, } 412 \text { Mann } \\
\text { Library, School of Integrative Plant Science } \\
\text { Nixon, Kevin; Cornell University, L. H. Bailey Hortorium, Plant Biology } \\
\text { Section, School of Integrative Plant Science, Cornell University } \\
\text { Crepet, William; Cornell University, Section of Plant Biology, 408 Mann } \\
\text { Library, School of Integrative Plant Science } \\
\text { Harbert, Robert; Cornell University, Section of Plant Biology, } 412 \text { Mann } \\
\text { Library, School of Integrative Plant Science } \\
\text { Daghlian, Charles; Dartmouth College, Electron Microscope Facility }\end{array}$ \\
\hline \hline Keyword: & \begin{tabular}{l} 
Clethraceae, Ericales, Late Cretaceous, New Jersey, glandular trichomes \\
\hline \hline
\end{tabular} \\
\hline \hline
\end{tabular}

\section{SCHOLARONE ${ }^{\text {m }}$}

Manuscripts 


\section{Title}

Rariglanda jerseyensis a new ericalean fossil flower from the Late Cretaceous of New Jersey

\section{Authors}

Camila Martínez ${ }^{1}$ : Section of Plant Biology, 408 Mann Library, School of Integrative Plant Science, Cornell University, Ithaca, New York 14853, USA; cm695@cornell.edu

Thereis Y. S. Choo: Section of Plant Biology, 412 Mann Library, School of Integrative Plant Science, Cornell University, Ithaca, New York 14853, USA; ytc4@cornell.edu

Daniella Allevato: Section of Plant Biology, 412 Mann Library, School of Integrative Plant Science, Cornell University, Ithaca, New York 14853, USA; dma227@cornell.edu

Kevin C. Nixon: Section of Plant Biology, 412 Mann Library, School of Integrative Plant Science, Cornell University, Ithaca, New York 14853, USA; kcn2@cornell.edu

William L. Crepet: Section of Plant Biology, 408 Mann Library, School of Integrative Plant Science, Cornell University, Ithaca, New York 14853, USA; wlc1@cornell.edu

Robert S. Harbert: Section of Plant Biology, 412 Mann Library, School of Integrative Plant Science, Cornell University, Ithaca, New York 14853, USA; rsh249@cornell.edu

Charles P. Daghlian: Electron Microscope Facility; 7605 Remsen, Dartmouth College, 74 College Street, Hanover, NH 03755 
${ }^{1}$ Corresponding author: Phone 607-255-1052; Fax: 607-254-5407 


\begin{abstract}
A new species, Rariglanda jerseyensis, is described from well-preserved fusainized fossil flowers collected from the Late Cretaceous of New Jersey. Phylogenetic analyses and comparisons with extant and extinct taxa place $R$. jerseyensis within the monophyletic Ericales, sister to Clethraceae. The most distinctive feature of $R$. jerseyensis is a dense covering of conspicuous multicellular trichomes on the abaxial surface of the calyx. These multicellular trichomes appear to be glandular, and similar trichomes are found in several other, unrelated, Late Cretaceous fossils. In particular, the ericalean fossil Glandulocalyx upatoiensis bears the most similarity to $R$. jerseyensis, although differences in androecium and trichome characters clearly separate the two taxa. In addition, phylogenetic analyses confirm the position of $G$. upatoiensis within the Ericales, but place it within the sarracenioid clade, in a polytomy with Actinidiaceae and Roridulaceae. Past ecological studies associating trichomes with defense against herbivores and pathogens, coupled with the prevalence of multicellular trichomes on flowers among different lineages of fossils in the Cretaceous, suggest that glandular trichomes could have been an important adaptation against herbivore feeding during the Cretaceous.
\end{abstract}

\title{
Key words
}

Clethraceae, Ericales, Late Cretaceous, New Jersey, glandular trichomes 


\section{Introduction}

The Late Cretaceous was a remarkable time in the evolutionary history of the angiosperms. Most of the major angiosperm groups that today dominate the environment were already present during that time (Wing and Boucher 1998; Crepet et al. 2004; Doyle 2015). Important diversification processes occurred, together with numerous adaptations of angiosperms to occupy different ecosystems. The study of the fossil record from this time interval is therefore fundamental to improving our understanding of the ecological and evolutionary success of the angiosperms (Crepet 2000).

Flower fossils from the Old Crossman Clay Pit from New Jersey provide a significant opportunity to study the Late Cretaceous evolutionary history of the angiosperms, as the remarkable three-dimensional preservation of these fossils facilitates the identification process. Fossil plants from all major lineages of land plants have been documented from this locality, including mosses, ferns, gymnosperms (Gandolfo et al. 1997, 2000, 2001) and many angiosperms. Within the angiosperms, groups that have been described include both early-diverging lineages like Nymphaeaceae, Calycanthaceae, Lauraceae, Chloranthaceae and Magnoliaceae (Herendeen et al. 1993; Crepet and Nixon 1994; Herendeen et al. 1994; Crepet and Nixon 1998b; Gandolfo et al. 2004; Crepet et al. 2005), and more derived lineages such as monocotyledons, rosids and early ericalean asterids (Crepet et al. 1992; Nixon and Crepet 1993; Crepet and Nixon 1998a; Gandolfo et al. 1998a; Zhou et al. 2001; Gandolfo et al. 2002; Hermsen et al. 2003; MartínezMillán et al. 2009; Crepet et al. 2013). Here, we describe a new fusainized (charcoalified) fossil flower morphotype, Rariglanda jerseyensis gen. et sp. nov., from the Old Crossman Clay Pit locality, using scanning electron microscopy (SEM) and CT-scans to 
provide a detailed characterization of its morphological features. A comparison of Rariglanda with extant and other fossil angiosperms, as well as phylogenetic analysis, suggest a taxonomic affinity within the (traditional) Ericales sensu stricto. Rariglanda jerseyensis also bears a superficially close resemblance to another Cretaceous flower from Georgia, Glandulocalyx upatoiensis Schönenberger, von Balthazar, Takahashi, Xiao, Crane \& Herendeen (Schönenberger et al. 2012).

Modern Ericales sensu lato (see APG III, 2009) contain approximately 6\% of extant eudicot diversity (Magallón et al. 1999), with more than 11,500 species. Before the use of molecular phylogenetic analyses, the 22 families that are today within the expanded Ericales, were placed in 12 orders across three different classes (APG III, 2009), although all families originally placed in the traditional Ericales are still considered to form a monophyletic group. The deep incongruences in the classification of the groups external to the core Ericales, based on either morphological or molecular characters, are now understood as a consequence of the wide morphological diversity of this order. This situation brings with it the intrinsic challenge of finding synapomorphic characters to define the expanded order, given that these characters may have been obscured by divergent evolutionary trends that could have begun as early as the Cretaceous, when the Ericales originated (Schönenberger et al. 2005, Magallón et al. 2014). However, the traditional core Ericales retain several features which are either synapomorphies or occur in the vast majority of species. The ericalean fossil record is rich, with about 81 fossils described, and at least 49 of those based on whole or partial flowers and fruits (MartínezMillán 2010). Some of the most important ericalean fossils include Cretaceous fusainized flowers from the United States, Sweden and Japan (Friis 1985; Nixon and Crepet 1993; 
Crepet 1996; Keller et al. 1996; Takahashi et al. 1999; Martínez-Millán et al. 2009;

Schönenberger and Friis, 2001; Schönenberger et al. 2012; Crepet et al. 2013). However, despite the exceptional preservation of these charcoalified flowers, taxonomic placement can often be difficult as these fossils may have unique combinations of characters relative to those of taxa within existing families (Martínez-Millán 2010). Phylogenetic analyses are therefore essential for determining the fossils' affinities.

\section{Materials and methods}

\section{Locality}

The fossil bed is located in the Old Crossman Clay Pit, in Sayreville, Middlesex County, New Jersey, USA, south of the Raritan River, $\left(40^{\circ} 28^{\prime}\right.$ N, $74^{\circ} 19^{\prime}$ W; Fig. 1). The fossils were collected from the South Amboy Fire Clay Member. The member consists of massive unconsolidated to laminated, dark gray clay, and contains lignitized plant fragments, charcoalified flowers, stems, wood fragments, fruits, and small pieces of amber that may have inclusions of plant or insect material (Sugarman et al. 2005). The unconsolidated clay-silt beds generally occur in channels, and are commonly adjacent to cross-bedded, fine to medium quartz sands with thin carbonaceous layers.

The Complexiopollenites exigua-Santalacites minor Zone has been consistently recognized in the South Amboy Fire Clay (Christopher 1979). The member is considered part of the upper member of the Raritan Formation (Christopher 1979), and the lowermost member of the Magothy Formation (Wolf and Pakiser 1971). The age of this zone has been mostly considered middle to late Turonian, possibly Coniacian 
(Christopher 1977; Doyle and Robbins 1977; Christopher 1979; Sirkin 1991; Grimaldi et al. 2000) but also post-Coniacian (Christopher 1982).

The Raritan and Magothy formations probably represent fluvial/deltaic deposition environments (Christopher 1979). The South Amboy Clay Member may represent the filling of old meanders that would correspond with a phase of marine regression (Christopher 1979)

\section{Fossil preparation}

Bulk samples from the Old Crossman Clay Pit were prepared following the method proposed by Friis (eg. 1985; described in detail by Martínez-Millán et al. 2009), which includes several washing and sieving steps, and a treatment with hydrofluoric acid. The fossils were observed and sorted under a Zeiss SV-11 stereomicroscope. The specimens from the species described here were mounted on SEM stubs and sputter-coated with gold/palladium to observe them in a field-emission Hitachi (Tokyo, Japan) S-4500 and a Jeol NeoScope JCM-5000 scanning electron microscope. All specimens are deposited in the L. H. Bailey Hortorium Paleobotany Collection, Department of Plant Biology, Cornell University with numbers CUPC- 1508 and 1579-1585. Five specimens were dissected to study the internal structure of the flower: CUPC-1508, 1579-80, 1583 and 1585. The micro-CT scanning was in this instance conducted at Dartmouth College Electron Microscope Facility for the holotype specimen CUPC1579 on a GE eXplore Locus Specimen micro-CT Scanner. 


\section{Phylogenetic analysis}

Preliminary exploratory analyses to identify families that included pentamerous and hypogynous flowers with free calices and corollas were undertaken by referring to literature and the herbarium collections of the L. H. Bailey Hortorium (BH). From these initial investigations we concluded that the fossil had a higher affinity with Ericales than with other orders of flowering plants.

Additionally, morphological similarities suggested that Rariglanda has a broad relationship to Glandulocalyx upatoiensis (Schönenberger et al. 2012), another Cretaceous fusainized flower from Georgia. Glandulocalyx was considered to be best placed within Ericales, and based on this as well as on our own preliminary study, we restricted our final phylogenetic analysis to Ericales sensu lato. Because of the shared characters, we also included Glandulocalyx in our final cladistic analyses. In their study of Glandulocalyx, Schönenberger et al. (2012) suggested a taxonomic affinity of the fossil with core Ericales, specifically Actinidiaceae or Clethraceae, but did not formally include it in a cladistics analysis. We conducted a morphologic phylogenetic analysis to estimate the phylogenetic position of the fossil, using as a scaffold a recent molecular phylogeny published by Löfstrand and Schönenberger (2015b). That topology included exemplar terminals for the major clades within core Ericales, while the outgroup comprised taxa from Ericales sensu lato, including Diapensiaceae, Styracaceae, Symplocaceae, Theaceae and Pentaphylacaceae. The terminals representing the fossil taxa were unconstrained in the analysis resulting in trees that were consistent with the molecular analysis proposed by Löfstrand and Schönenberger (2015b) for extant taxa, with placement of the two fossil taxa based solely on morphology. The matrix comprised 
25 taxa (Appendix A1), representing exemplar genera from all families and major clades in the core Ericales, and 13 morphological characters (Appendix A2). The final morphological matrix included only characters that could be observed in the fossil taxa, and were scored based on published descriptions or matrices (e.g. Luteyn et al. 1995; Kron et al. 2002; Millán and Crepet 2014; Löfstrand and Schönenberger 2015a), and direct observations from herbarium specimens from $\mathrm{BH}$. All molecular characters were coded as missing for both fossils. Parsimony analyses were performed using TNT (Goloboff et al. 1998) and the parsimony ratchet (Nixon 1999). In the TNT analyses, ten sets of 200 iterations using a $10 \%$ perturbation of characters were used for the ratchet analyses, and default values for drift, sectorial search and tree fusion were used. Visualization of character distributions was performed with Winclada ver. 1.99 (Nixon 2015).

\section{Results}

\section{Systematics}

Order — Ericales sensu APG (2003)

Family - Core Ericales, near Clethraceae

Genus — Rariglanda Martinez \& Choo, gen. nov.

Type species — Rariglanda jerseyensis Martinez \& Choo

Generic diagnosis - Flowers bisexual, actinomorphic, hypogynous, pentamerous. Calyx and corolla aestivation quincuncial. Sepals 5, free; adaxially glabrous, abaxial surface covered in shortly stalked multicellular capitate glandular trichomes, these mostly globose with an apical indentation. Petals alternate with sepals, free, and thin. 
Androecium of ten stamens of uniform size; anthers with two sporangia and a hollow apical protrusion. Pollen small, spheroidal, tricolporate, striate/rugulate. Gynoecium syncarpous, tricarpellate, styles 3, basally fused; stigmas not observed. Ovary trilocular, placentation axile, ovules numerous.

Etymology — Named for the Raritan formation and the Raritan river of New Jersey and for the conspicuous glandular hairs on the calyx Rariglanda jerseyensis Martinez \& Choo, sp. nov. (Fig. 2-5)

Holotype - CUPC 1579. Deposited in the L. H. Bailey Hortorium

Paratypes - CUPC 1508, 1580-1585

Repository - Cornell University Paleobotany Collection, L. H. Bailey Hortorium, Department of Plant Biology, Cornell University, Ithaca, New York.

Type locality — Old Crossman Clay Pit, in Sayreville, Middlesex County, New Jersey, USA

Stratigraphic position — South Amboy Fire Clay Member, considered upper Raritan Formation

Age - Turonian-Coniacian, Late Cretaceous.

Etymology — Named after New Jersey, USA, where the fossil was collected.

Specific diagnosis - As for the genus.

Description - One charcoalified flower, in unopened bud, was completely preserved (Holotype: CUPC 1579). Flowers bisexual, actinomorphic. Flower bud (late preanthesis) $1.2-1.4 \mathrm{~mm}$ in height by $0.9-2 \mathrm{~mm}$ in diameter. Sepals enclose remaining floral organs (Fig. 2a). The scan of the unopened bud showed a large preservational fracture through 
the gynoecium, obscuring some of the gynoecium details (Fig. 4a: arrow pointing to the crack, supplementary video S1).

Calyx

The calyx is pentamerous and has quincuncial aestivation (Fig. 4f-g); all sepals are free and roughly triangular with an obtuse tip (Fig. 2a); sepals are approximately $0.9-1.3 \mathrm{~mm}$ in length and $0.6-0.9 \mathrm{~mm}$ in width, with a midvein; the outer sepals are slightly larger than the inner ones (e.g specimen 1579: outer sepal is $0.8 \mathrm{~mm}$ and inner sepal is $0.5 \mathrm{~mm}$ in width; Fig. 4); the adaxial surfaces of the sepals are glabrous (Fig. 2c), and the entire abaxial surface of each sepal is densely covered with large, multicellular, glandular trichomes (Fig. 2a,b) that are shortly stalked (Fig. 3a) and generally globose, but with a prominent central indentation (Fig. 3b). Glands average $241 \mu \mathrm{m}$ in diameter, and with considerable variation in size (standard deviation: $59.3 \mu \mathrm{m}$ ). The smallest glands are located towards the margins and tips of the sepals; within the glands, the individual cells are smaller towards the differentiated center and appear to radiate spirally outwards from the central indentation (Fig. 3b); the cuticle layer of the glands is thick (Fig. 2b).

\section{Corolla}

The five petals are separated from each other and also show quincuncial aestivation (Fig. $4 \mathrm{f}-\mathrm{g}$ ); the bases of the petals are broad and alternately arranged with the sepals (Fig. $4 \mathrm{a})$, and the apices of the petals are convolute in bud (Fig. 4e); the petals appear to be thin and obtusely shaped, comparable in size and shape to the sepals. The vascular trace of a midrib is visible in one specimen.

Androecium 
Stamens are free and in a diplostemonous arrangement (Fig. 4); filaments are broad and short. Anthers are attached adaxially and composed of one longitudinally elongated pollen sac arranged on either side of the connective and have an apical protrusion or cavity (Fig. 2d-e). Pollen grains preserved on the outer surface of the gynoecium in two specimens are tricolporate and $12-14 \mu \mathrm{m}$ in length; the pollen ornamentation is striate (Fig. 5).

\section{Gynoecium}

The gynoecium is superior and composed of three syncarpous carpels and is $2 \mathrm{~mm}$ in height and $1.1 \mathrm{~mm}$ in width; the ovary is ovoid and trilocular (Fig. 2f, g), with thick ovary walls and a prominent line dividing each carpel (Fig. 2g, h). Each locule bears numerous $(>5)$ ovules on axile placentae (Fig. $2 \mathrm{~h}$ ). The styles are fused at the base, becoming separate presumably stigmas towards the apex. The cross section of the styles at the apex of the ovary shows three separate stylar canals that are surrounded by a ring of tissue (Fig. 2g).

\section{Comparison with other similar fossils}

We compared the floral characters of Rariglanda jerseyensis with eight similar fossil flowers from the Late Cretaceous that have previously been placed in Ericales (Table 1). The eight species included in the comparison all have a pentamerous calyx and corolla, and superior ovaries with numerous ovules in common with $R$. jerseyensis. Most of these species have calyces and corollas with quincuncial aestivation, multicellular trichomes on the abaxial surfaces of the sepals and three carpels. However, the number of stamens is very variable in these fossils, ranging from five to numerous (Table 1). Stamen number is extremely important in differentiating genera and families within Ericales. 
Glandulocalyx upatoiensis is most similar to Rariglanda jerseyensis based on its overall morphology and presence of adaxial sepal glands but there are notable differences including stamen number, anther morphology, and the distribution and structure of the glandular trichomes. Glandulocalyx upatoiensis does not have glandular trichomes at the tips of the sepals and these glands lack the apical indentation characteristic of calyx glands of $R$. jerseyensis. The number of stamens in G. upatoiensis varies from 20-28, instead of ten as found in Rariglanda. Although the stamens observed in R. jerseyensis are in an earlier developmental stage than those observed in G. upatoiensis, they are clearly very different in morphology. Glandulocalyx upatoiensis has sagittate, dithecal, tetrasporangiate anthers, while $R$. jerseyensis has non-sagittate dithecal anthers with a hollow apical protrusion.

Parasaurauia allonensis, another Cretaceous ericalean fossil, also shares characters with Rariglanda jerseyensis, including the same floral formula (Keller et al. 1996, Fig. 31). However, the multicellular trichomes of Parasaurauia are completely different from those of Rariglanda being non-capitate and elongated. In addition, in Parasaurauia stamens are unequal, with 5 long and 5 shorter filaments; the anthers are deeply sagittate, and the styles are free.

Results of the phylogenetic analysis

Four most parsimonious trees of 3681 steps, $0.90 \mathrm{RI}$ and $0.73 \mathrm{CI}$ were found; the strict consensus tree is shown in Fig. 6. The analysis places Rariglanda jerseyensis within the monophyletic ericoid clade as the sister taxon to Clethra alnifolia (Clethraceae), while Glandulocalyx upatoiensis is nested within the monophyletic sarracenioid clade and is in an unresolved polytomy, alternatively as a sister to Actinidiaceae or to Roridulaceae in 
the most parsimonious solutions. Characters such as presence of multicellular trichomes on the sepals, number of stamens and carpels, and style fusion were important characters determining the phylogenetic position of the fossils and are shown in Fig. 7.

\section{Discussion}

One of the most remarkable characteristics of Rariglanda jerseyensis is the presence of capitate multicellular trichomes on the calyx. Whether the multicellular trichomes are glands secreting enzymes, polysaccharides, sugar, oils or inorganic salts cannot be established based on the fossil material, however, their presence in both Rariglanda and Glandulocalyx suggests similar adaptations to some environmental factors. Ecological studies suggest that trichomes may serve as the first line of defense against herbivores and pathogens (Peiffer et al. 2009). High densities of trichomes like those observed in Rariglanda jerseyensis can directly impede herbivore feeding by serving as a physical and/or chemical barrier to their movement and feeding (Peiffer et al. 2009). The high number of flower fossils bearing multicellular and possibly glandular trichomes from the Cretaceous, such as Glandulocalyx upatoiensis (Schönenberger et al. 2012), Parasaurauia allonensis (Keller et al. 1996), Paleoenkianthus sayrevillensis (Nixon and Crepet 1993) and Raritaniflora glandulosa (Crepet et al. 2013), together with Rariglanda jerseyensis and other undescribed material from the Old Crossman Clay Pit, suggest that glandular trichomes may have been an important adaptation against herbivores during the Cretaceous. The Cretaceous is one of the most significant periods of insect evolution, since many modern families within phytophage lineages like Lepidoptera, Hemiptera and Orthoptera, appeared during this time (Grimaldi and Engel 2005). The high diversity of 
phytophagous insects during the Cretaceous probably reflects the coevolutionary history of these with angiosperms, given that flowering plants are generally more digestible and have more nutritional value than other plant groups (Grimaldi and Engel 2005). The presence of these glands on flowers also may suggest that pollinators were less specialized, and their behavior included more generalized herbivory in addition to nectar and/or pollen collection.

The distribution of glandular hairs or multicellular trichomes on vegetative and reproductive organs tends to be variable within modern Ericales, sporadically distributed, and not strongly correlated with well-defined clades. Although in our analysis the absence of multicellular trichomes on the sepals appears as a synapomorphy for the ericoid clade (Fig.7b), there are various taxa within this clade, but not included in the analysis, that have multicellular trichomes on the sepals, such as Rhododendron and Bejaria. Remarkably, the evolution of related structures like the digestive glands of Sarraceniaceae containing proteolytic enzymes, and the prominent multicellular capitate glands of Roridulaceae shows the importance of these structures in certain groups within Ericales.

Within extant Ericales, Clethraceae was found to be most closely related to Rariglanda jerseyensis. Clethraceae includes two genera and 75 species and is today also distributed in temperate and montane tropical North and South America, where several species are present. The family is also distributed in tropical to subtropical regions of South East Asia, and most species occupy montane habitats, and are sometimes found growing in acidic soils (Gustafsson 2004). Clethra species typically have drooping or pendant flowers, with apical anther dehiscence, a syndrome commonly associated with buzz 
pollination by bees. The pollination syndrome for Clethra alnifolia L. has been described as associated with bumblebees (Bhattacharya et al. 2003). The floral morphology of Rariglanda jerseyensis, with small flowers with free petals might also be associated with a bee-pollination syndrome, although the nature of anther dehiscence in the fossil is unknown.

Pollen in the ericalean clade is generally characterized by having small size, $(2-) 3(-5)-$ colporate apertures and variable surface ornamentation (Zhang and Anderberg 2002). Specifically, the pollen grains of Clethra are also small-sized and tricolporate, with surface ornamentation that varies by species, from psilate to rugulate (Zhang and Anderberg 2002). The pollen grains found associated with Rariglanda jerseyensis are spheroidal, small, tricolporate, and striate/rugulate (Fig. 5). Neither of the pollen grains from $R$. jerseyensis was found directly on the stamens, however, more than two of such pollen grains were found on more than one flower suggesting that the pollen was associated with Rariglanda. The shared characters between pollen from the core ericalean clade and the pollen found associated with $R$. jerseyensis are consistent with the phylogenetic placement proposed here.

Recent studies of the sarracenioid clade within Ericales that included morphological and molecular analyses also reviewed taxonomic affinities for the fossils Glandulocalyx upatoiensis and Parasaurauia allonensis and suggested likely affinities for both fossils with Actinidiaceae (Löfstrand and Schönenberger 2015a,b). Some of the floral characters supporting this suggested affinity are: late anther inversion; pendant placentae in Glandulocalyx; ovules arranged in longitudinal rows; pluriseriate trichomes present on sepals and capitate stigmas with ventral grooves (Löfstrand and Schönenberger 2015a,b). 
Our phylogenetic analysis for G. upatoiensis is largely congruent with these studies, given that the fossil was found nested within the sarracenioid clade, although a sister relationship with either Roridulaceae or Actinidiaceae was equally parsimonious. In our analysis, other characters such as number of stamens and carpels and style fusion were informative for the phylogenetic placement (Fig. 7). Specifically, the difference in the number of carpels between G. upatoiensis and Actinidiaceae, was an important character placing G. upatoiensis outside Actinidiaceae (Fig. 7c). Other characters such as anther inversion, protruded placenta and a depression at the apex of the ovary were not included in the analysis because occurrence of these characters in Rariglanda jerseyensis was unknown, but should be considered for future analyses for Glandulocalyx upatoiensis. Parasaurauia $\square$ allonensis shares its floral formula with that $R$. jerseyensis, but there are also numerous differences (see results). The great morphological variation within Ericales and the difficulties determining synapomorphic characters for the group might obscure the phylogenetic position of the fossil, however, given that the array of characters of $R$. jerseyensis is found in various ericalean lineages, it is safe to assume that $R$. jerseyensis is an early divergent lineage of the Ericales.

\section{Acknowledgments}

The authors thank Jennifer Svitko for SEM, laboratory preparations and CT-scan video, Dr. Maria A. Gandolfo for valuable collaboration during the study and Dr. Paula Mikkelsen from the Paleontological Research Institution for assistance on taking SEM photographs. C. Martínez acknowledges the support from the Colciencias-Fulbright fellowship from Colombia. 


\section{References}

APG [Angiosperm Phylogeny Group] III. 2009. An update of the Angiosperm Phylogeny Group classification for the orders and families of flowering plants: APG III. Bot. J. Linnean Soc. 161: 105-121. doi: 10.1111/j.1095-8339.2009.00996.x

Bhattacharya, M., Primack, R.B., Gerwein, J. 2003. Are roads and railroads barriers to bumblebee movement in a temperate suburban conservation area? Biol. Cons. 109: 3745. doi:10.1016/S0006-3207(02)00130-1

Christopher, R.A. 1977. Selected Normapolles pollen genera and the age of the Raritan and Magothy Formations (Upper Cretaceous) of northern New Jersey. In Field guide to Cretaceous and lower Tertiary beds of the Raritan and Salisbury embayments, New Jersey, Delaware, and Maryland: AAPG/SEPM field guide. Edited by J.P. Owens, Sohl, N.F. and Minard J.P., American Association of Petroleum Geologists Society, Economy Paleontology Mineralogy Guidebook. Annual Convention, Washington, D.C., USA. pp 58-69.

Christopher, R.A. 1979. Normapolles and triporate pollen assemblages from the Raritan and Magothy Formations (Upper Cretaceous) of New Jersey. Palynology 3: 73-121. doi: 10.1080/01916122.1979.9989185.

Christopher, R.A. 1982. The Occurrence of the Complexiopollis-Atlantopollis Zone (Palynomorphs) in the Eagle Ford Group (Upper Cretaceous) of Texas. Journal of Paleontol. 56: 525-541.

Crepet, W.L. 1996. Timing in the evolution of derived floral characters: Upper Cretaceous (Turonian) taxa with tricolpate and tricolpate-derived pollen. Rev. Palaeobot. Palynol. 90: 339-359. doi: 10.1016/0034-6667(95)00091-7. 
Crepet, W.L. 2000. Progress in understanding angiosperm history, success, and relationships: Darwin's abominably “perplexing phenomenon”. Proc. Natl. Acad. Sci. USA. 97: 12939_ 12941. doi: 10.1073/pnas.97.24.12939

Crepet, W.L., and Nixon, K.C. 1994. Flowers of Turonian Magnoliidae and their implications. In Early Evolution of Flowers. Edited by P.K. Endress and E.M. Friis. Springer Vienna, Vienna. pp. 73-91.

Crepet, W., and Nixon, K. 1998. Fossil Clusiaceae from the Late Cretaceous (Turonian) of New Jersey and implications regarding the history of bee pollination. Am. J. Bot. 85: 11221122.

Crepet, W.L., and Nixon, K.C. 1998. Two new fossil flowers of magnoliid affinity from the Late Cretaceous of New Jersey. Am. J. Bot. 85: 1273-1288.

Crepet, W.L., Nixon, K.C., Friis, E.M., and Freudenstein, J.V. 1992. Oldest fossil flowers of hamamelidaceous affinity, from the Late Cretaceous of New Jersey. Proc. Natl. Acad. Sci. USA. 89: 8986-8989. doi: 10.1073/pnas.89.19.8986.

Crepet, W.L., Nixon, K.C. and Gandolfo, M.A., 2004. Fossil evidence and phylogeny: the age of major angiosperm clades based on mesofossil and macrofossil evidence from Cretaceous deposits. Am. J. Bot. 91: 1666-1682. doi: 10.3732/ajb.91.10.1666.

Crepet, W.L., Nixon, K.C., and Gandolfo, M.A. 2005. An extinct calycanthoid taxon, Jerseyanthus calycanthoides, from the Late Cretaceous of New Jersey. Am. J. Bot. 92: 1475-1485. doi: 10.3732/ajb.92.9.1475

Crepet, W.L., Nixon, K.C., and Daghlian, C.P. 2013. Fossil Ericales from the Upper Cretaceous of New Jersey. Int. J. Plant Sci. 174: 572-584. doi: 10.1086/668689

Doyle, J.A., and Robbins, E.I. 1977. Angiosperm pollen zonation of the continental Cretaceous 
of the Atlantic coastal plain and its application to deep wells in the Salisbury embayment. Palynology 1: 41-78. doi: 10.1080/01916122.1977.9989150.

Doyle, J.A. 2015. Recognising angiosperm clades in the Early Cretaceous fossil record. Hist. Biol., 27, 414-429. doi: 10.1080/08912963.2014.938235

Friis, E.M. 1985. Actinocalyx gen. nov., sympetalous angiosperm flowers from the Upper Cretaceous of southern Sweden. Rev. Palaeobot. Palynol. 45: 171-183. doi: 10.1016/0034-6667(85)90001-6.

Gandolfo, M., Nixon, K., Crepet, W., and Ratcliffe, G. 1997. A new fossil fern assignable to Gleicheniaceae from Late Cretaceous sediments of New Jersey. Am. J. Bot. 84: 483-483. Gandolfo, M., Nixon, K., and Crepet, W. 1998. A new fossil flower from the Turonian of New Jersey: Dressiantha bicarpellata gen. et sp. nov. (Capparales). Am. J. Bot. 85: 964-964.

Gandolfo, M.A., Nixon, K.C., and Crepet, W.L. 2001. Turonian Pinaceae of the Raritan Formation, New Jersey. Plant Syst. Evol. 226: 187-203. doi: 10.1007/s006060170065. Gandolfo, M.A., Nixon, K.C., and Crepet, W.L. 2002. Triuridaceae fossil flowers from the Upper Cretaceous of New Jersey. Am. J. Bot. 89: 1940-1957. doi: 10.3732/ajb.89.12.1940

Gandolfo, M.A., Nixon, K.C., and Crepet, W.L. 2004. Cretaceous flowers of Nymphaeaceae and implications for complex insect entrapment pollination mechanisms in early angiosperms. Proc. Natl. Acad. Sci. USA. 101: 8056-8060. doi: 10.1073/pnas.0402473101.

Goloboff, P. 1998. Nona. Computer program and software. Published by the author. Tucuman, Argentina.

Grimaldi, D. and Engel, M. 2005. Evolution of insects. Cambridge University Press. Cambridge, Massachusetts, USA. 
Grimaldi, D., Shedrinsky, A., and Wampler, T.P. 2000. A remarkable deposit of fossiliferous amber from the Upper Cretaceous (Turonian) of New Jersey. In Studies on fossils in amber, with particular reference to the Cretaceous of New Jersey. Edited by D. Grimaldi. pp. $1-76$.

Gustafsson, C. 2004. Clethraceae. In Flowering plants of the Neotropics. Edited by N. Smith, S.A. Mori, A. Henderson, D.W. Stevenson and S.V. Heald. Princeton University Press, Princeton, pp. 104-105.

Herendeen, P.S., Crepet, W.L., and Nixon, K.C. 1993. Chloranthus_like stamens from the Upper Cretaceous of New Jersey. Am. J. Bot. 80: 865-871.

Herendeen, P.S., Crepet, W.L., and Nixon, K.C. 1994. Fossil flowers and pollen of Lauraceae from the Upper Cretaceous of New Jersey. Plant Syst. Evol. 189: 29-40. doi: 10.1007/BF00937576.

Hermsen, E.J., Gandolfo, M.A., Nixon, K.C., and Crepet, W.L. 2003. Divisestylus gen. nov. (aff. Iteaceae), a fossil saxifrage from the Late Cretaceous of New Jersey, USA. Am. J. Bot. 90: 1373-1388. doi: 10.3732/ajb.90.9.1373.

Keller, J.A., Herendeen, P.S., and Crane, P.R. 1996. Fossil flowers and fruits of the Actinidiaceae from the Campanian (Late Cretaceous) of Georgia. Am. J. Bot. 83: 528541. doi: $10.2307 / 2446221$.

Kron, K.A., Judd, W.S., Stevens, P.F., Crayn, D.M., Anderberg, A.A., Gadek, P.A., Quinn C.J., and Luteyn, J.L. 2002. Phylogenetic classification of Ericaceae: molecular and morphological evidence. Bot. Rev. 68: 335-423. doi: 10.1663/00068101(2002)068[0335:PCOEMA]2.0.CO;2.

Löfstrand, S. D., and Schönenberger, J. 2015a. Comparative floral structure and systematics in 
the sarracenioid Clade (Actinidiaceae, Roridulaceae and Sarraceniaceae) of Ericales. Bot. J. Linn. Soc. 178: 1-46. doi: 10.1111/boj.12266.

Löfstrand, S. D., and Schönenberger, J. 2015b. Molecular phylogenetics and floral evolution in the sarracenioid Clade (Actinidiaceae, Roridulaceae and Sarraceniaceae) of Ericales. Taxon. 64: 1209-24. doi: 10.12705/646.6.

Luteyn, J.L., Judd, W.S., Clemants, S.E., Diggs, G.M., Sorensen, P.D., Dorr, L.J. and Wallace G.D. 1995. Ericaceae-Part II. The superior-ovaried genera (Monotropoideae, Pyroloideae, Rhododendroideae, and Vaccinioideae p.p.). Flora Neotropica. Monograph 66. New York Botanical Garden, Bronx, New York, USA.

Magallón, S., Crane, P.R., and Herendeen, P.S. 1999. Phylogenetic pattern, diversity, and diversification of eudicots. Ann. Mo. Bot. Gard. 86: 297-372. doi: 10.2307/2666180.

Magallón, S., Gomez-Acevedo, S., Sanchez-Reyes. L.L., and Hernandez, T. 2015. A metacalibrated time-tree documents the early rise of flowering plant phylogenetic diversity. New Phytol. 207: 437-453. doi: 10.1111/nph.13264

Martínez-Millán, M. 2010. Fossil record and age of the Asteridae. Bot. Rev. 76: 83-135. doi: 10.1007/s12229-010-9040-1.

Martínez-Millán, M., and Crepet, W.L. 2014. The fossil record of the Solanaceae revisited and revised- the fossil record of Rhamnaceae enhanced. Bot. Rev. 80: 73-106. doi: 10.1007/s12229-014-9134-2.

Martínez-Millán, M., Crepet, W.L., and Nixon, K.C. 2009. Pentapetalum trifasciculandricus gen. et sp. nov., a thealean fossil flower from the Raritan Formation, New Jersey, USA (Turonian, Late Cretaceous). Am. J. Bot. 96: 933-949. doi: 10.3732/ajb.0800347.

New Jersey Geological Survey. 2005. Geologic map of New Jersey, scale 1:1.000.000. 
Department of Environmental Protection [online]. Available from http://www.state.nj.us/dep/njgs/njgeol.htm [accessed 25 November 2015].

Nixon, K.C. 1999. The Parsimony Ratchet, a new method for rapid parsimony analysis. Cladistics. 15: 407-414. doi: 10.1111/j.1096-0031.1999.tb00277.x

Nixon, K.C. 2015. Winclada ver. 1.99. Published by the author, Ithaca, NY [Available at http://www.cladistics.com].

Nixon, K.C., and Crepet, W.L. 1993. Late Cretaceous fossil flowers of ericalean affinity. Am. J. Bot. 80: 616-623.

Peiffer, M., Tooker, J.F., Luthe, D.S., and Felton, G.W. 2009. Plants on early alert: glandular trichomes as sensors for insect herbivores. New Phytol. 184: 644-656. doi: 10.1111/j.1469-8137.2009.03002.x.

Schönenberger, J. and Friis, E.M. 2001. Fossil flowers of ericalean s.l. affinity from the Late Cretaceous of southern Sweden. Am. J. Bot. 88: 467-480.

Schönenberger, J., Anderberg, Arne A., and Sytsma, Kenneth J. 2005. Molecular phylogenetics and patterns of floral evolution in the Ericales. Int. J. Plant Sci. 166: 265-288. doi: $10.1086 / 427198$.

Schönenberger, J., von Balthazar, M., Takahashi, M., Xiao, X., Crane, P.R., and Herendeen P.S. 2012. Glandulocalyx upatoiensis, a fossil flower of Ericales (Actinidiaceae/ Clethraceae) from the Late Cretaceous (Santonian) of Georgia, USA. Ann Bot. 109: 921-936. doi: $10.1093 / \mathrm{aob} / \mathrm{mcs} 009$.

Sirkin, L. 1991. Stratigraphy of the long island platform. J. Coast. Res. 11: 217-227. Sugarman, P.J., Stanford, S.D., Owens, J.P., and Brenner, G.J. 2005. Bedrock geology of the South Amboy Quadrangle Middlesex and Monmouth Counties, New Jersey. New Jersey 
Geological Survey Open- File Map OFM 65, scale 1:24000. Department of Environmental Protection, New Jersey Geological Survey. Trenton, New Jersey, USA

Takahashi, M., Crane, P.R., and Ando, H. 1999. Fossil flowers and associated plant fossils from the Kamikitaba Locality (Ashizawa Formation, Futaba Group, Lower Coniacian, Upper Cretaceous) of Northeast Japan. J. Plant Res. 112: 187-206. doi: http://dx.doi.org/10.1007/PL00013872.

Wing, S.L., and Boucher, L.D. 1998. Ecological aspects of the Cretaceous flowering plant radiation. Annu. Rev. Earth Planet. Sci. 26: 379-421. doi: 10.1146/annurev.earth.26.1.379.

Wolfe, J.A., and Pakiser, H.M. 1971. Stratigraphic interpretations of some Cretaceous microfossil floras of the Middle Atlantic States. US Geol. Surv. Prof. Paper. 750: B35B47.

Zhang, X.P. and Anderberg, A.A. 2002. Pollen morphology in the ericoid clade of the order Ericales, with special emphasis on Cyrillaceae. Grana. 41: 201-215. doi: $10.1080 / 001731302321011997$.

Zhou, Z.-k., Crepet, W.L., and Nixon, K.C. 2001. The earliest fossil evidence of the Hamamelidaceae: Late Cretaceous (Turonian) inflorescences and fruits of Altingioideae. Am. J. Bot. 88: 753-766. 
Table 1. Comparative table of fossil flower species from the Late Cretaceous similar to Rariglanda jerseyensis

\begin{tabular}{|c|c|c|c|c|c|c|c|c|c|c|c|}
\hline \multirow[b]{2}{*}{ Species } & \multirow[b]{2}{*}{ Locality } & \multirow[b]{2}{*}{ Age } & \multirow[b]{2}{*}{ Reference } & \multirow[b]{2}{*}{$\begin{array}{c}\text { Calyx } \\
\text { aestivation }\end{array}$} & \multirow[b]{2}{*}{ Calyx } & \multirow[b]{2}{*}{$\begin{array}{c}\text { Calyx } \\
\text { trichomes }\end{array}$} & \multirow[b]{2}{*}{ Corolla } & \multirow[b]{2}{*}{$\begin{array}{c}\text { Anther } \\
\text { attachment }\end{array}$} & \multicolumn{3}{|c|}{ Number of } \\
\hline & & & & & & & & & Stamens & Carpels & Styles \\
\hline Rariglanda jerseyensis & NJ, USA & Turonian & This study & Quincuncial & Free & $\begin{array}{l}\text { Abaxial / } \\
\text { capitate }\end{array}$ & Free & Basal & 10 & 3 & 3 \\
\hline Glandulocalyx upatoiensis & GA, USA & Santonian & $\begin{array}{l}\text { Schönenberger } \\
\text { et al., } 2012\end{array}$ & Quincuncial & Free & $\begin{array}{l}\text { Abaxial / } \\
\text { capitate }\end{array}$ & Free & Ventral & $20-28$ & 3 & 3 \\
\hline Parasaurauia allonensis & GA, USA & Campanian & $\begin{array}{l}\text { Keller et al., } \\
1996\end{array}$ & Quincuncial & Free & $\begin{array}{l}\text { Abaxial / } \\
\text { elongate }\end{array}$ & Free & Basal & 10 & 3 & 3 \\
\hline Pentapetalum trifasciculandricus & NJ, USA & Turonian & $\begin{array}{l}\text { Martínez-Millán } \\
\text { et al., } 2009\end{array}$ & Quincuncial & Free & Absent & Free & Basal & $\infty$ & 3 & 3 \\
\hline Paleoenkianthus sayrevillensis & NJ, USA & Turonian & $\begin{array}{l}\text { Nixon and } \\
\text { Crepet, } 1993\end{array}$ & Imbricate & $\begin{array}{l}\text { Basally } \\
\text { connate }\end{array}$ & $\begin{array}{c}\text { Abaxial/ } \\
\text { multicellular? }\end{array}$ & $\begin{array}{l}\text { Partially } \\
\text { connate }\end{array}$ & Basal & 8 & 4 & 4 \\
\hline Paradinandra suecica & $\begin{array}{l}\text { Asen, } \\
\text { Sweden }\end{array}$ & $\begin{array}{l}\text { Campanian-- } \\
\text { Santonian }\end{array}$ & $\begin{array}{l}\text { Schönenberger } \\
\text { and Friis, } 2001\end{array}$ & Quincuncial & Free & $\begin{array}{c}\text { Abaxial / } \\
\text { unicellular }\end{array}$ & $\begin{array}{l}\text { Partially } \\
\text { connate }\end{array}$ & Basal & 15 & 3 & 3 \\
\hline Actinocalyx bohrii & $\begin{array}{l}\text { Asen, } \\
\text { Sweden }\end{array}$ & $\begin{array}{l}\text { Campanian-- } \\
\text { Santonian }\end{array}$ & Friis, 1985 & Imbricate & Free & Absent & Connate & Basal & 5 & 3 & 3 \\
\hline Raritaniflora glandulosa & NJ, USA & Turonian & $\begin{array}{l}\text { Crepet et al., } \\
2013\end{array}$ & Valvate & Connate & $\begin{array}{l}\text { Abaxial / } \\
\text { capitate }\end{array}$ & Free & Dorsal & 5 & 5 & 1 \\
\hline
\end{tabular}




\section{Figure captions}

Figure 1. Location of the Old Crossman Clay Pit and surface geology of the area. Modified from maps downloaded from http://www.state.nj.us/dep/njgs/pricelst/gmseries.htm. The map on the left shows the surface geology of New Jersey, USA (New Jersey Geological Survey Map 1:1.000.000, 2005). In grey are Paleozoic rocks, Precambrian rocks and metamorphic and igneous rocks; in green are Mesozoic rocks; and in yellow are Cenozoic rocks. The map on the right shows the zoomed area of the grey square and the location of the Old Crossman Clay Pit (red arrow). Kms: South Amboy Fire Clay; Kmo: Old bridge sand; Krw: Woodbridge Clay (Sugarman et al. 2005).

Figure 2. SEM photographs from Rariglanda jerseyensis. (a) CUPC 1584: up-side view from the flower bud close to anthesis; (b) CUPC 1581: adaxial side of the sepal; (c) CUPC 1579: abaxial side of the sepal; (d) CUPC 1579: dissected flower bud showing the stamens; (e) CUPC 1579: close-up of the stamens in the early developmental stages; (f) CUPC 1508: gynoecium; (g) CUPC 1583: three free styles; (h) CUPC 1580: ovary with multiple ovules. Scales (a-c) $500 \mu \mathrm{m}$; (d) $200 \mu \mathrm{m}$; (e) $50 \mu \mathrm{m}$; (f, g) $600 \mu \mathrm{m}$; (h) $300 \mu \mathrm{m}$. Figure 3. SEM photographs of multicellular glands of Rariglanda jerseyensis. (a) CUPC 1504: side view if the sepal showing the short-stalked gland. (b) CUPC 1581: up-side view from the gland showing the central indentation and variation in cell size. (a and b) scales $=100 \mu \mathrm{m}$ 
Figure 4. Rariglanda jerseyensis CUPC 1579 (a-e) Screenshots from the CT-scan movie (left; supplementary video S1) and drawings of the reconstruction of its floral characters (right). Calyx is in black with white border; corolla is in white; androecium is in gray; and gynoecium is in gray with white border. Scale $=0.5 \mathrm{~mm}$. Screenshots are organized from base to apex of the flower bud. (a) basal section of the flower bud; (b-d) basal to middle sections; (e) apical section; (f) simplified floral diagram; and (g) simplified reconstruction.

Figure 5. SEM photograph of pollen of Rariglanda jerseyensis illustrating striate micromorphology and the endoaperturial bulge in one of the apertures. Scale: $5 \mu \mathrm{m}$. Figure 6. Strict consensus tree of four equally most parsimonious trees of 3681 steps. CI 0.90, RI 0.73. Rariglanda jerseyensis (in bold font) is nested within the ericoid clade and is sister to the modern genus Clethra. Glandulocalyx upatoiensis (in bold font) is nested within the sarracenioid clade in a polytomy with Roridulaceae and Actinidiaceae.

Figure 7. Ancestral character-state reconstruction for: (a) number of stamens; (b) presence of multicellular trichomes on the sepals; (c) number of carpels; (d) style fusion. Rariglanda jerseyensis and Glandulocalyx upatoiensis are in bold font. See color code for character states. 


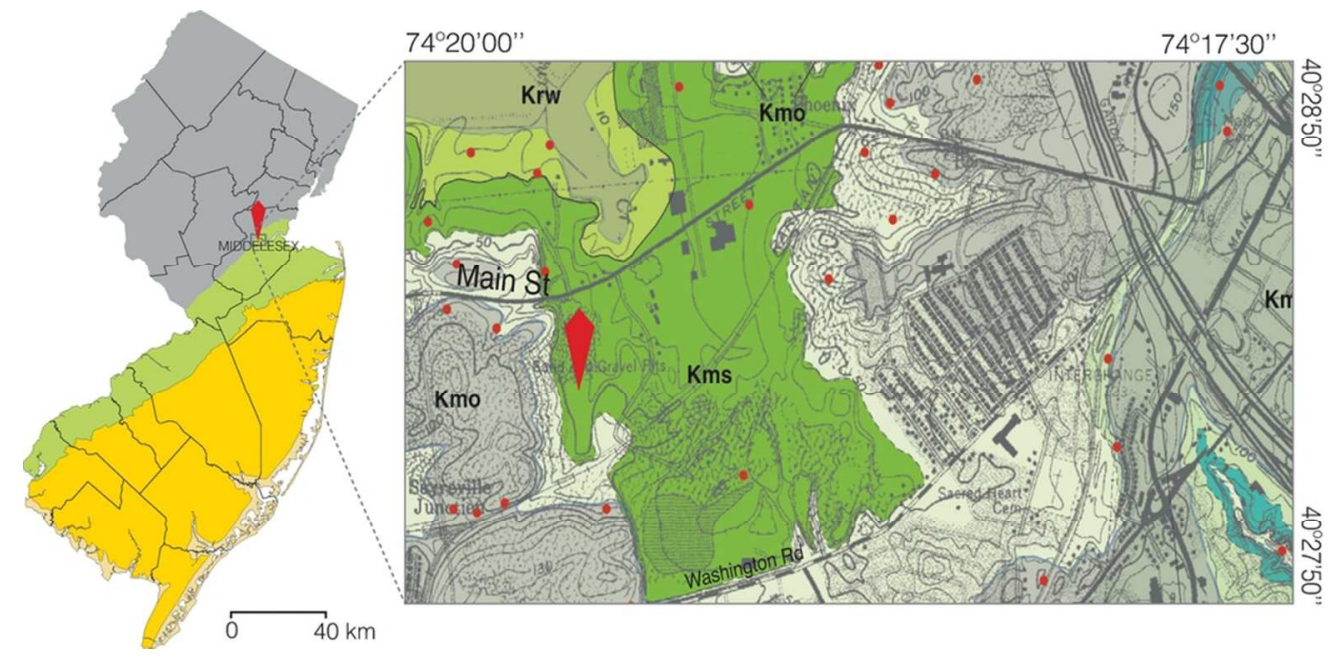

Fig.1_Map fossil locality $86 \times 42 \mathrm{~mm}(300 \times 300 \mathrm{DPI})$ 


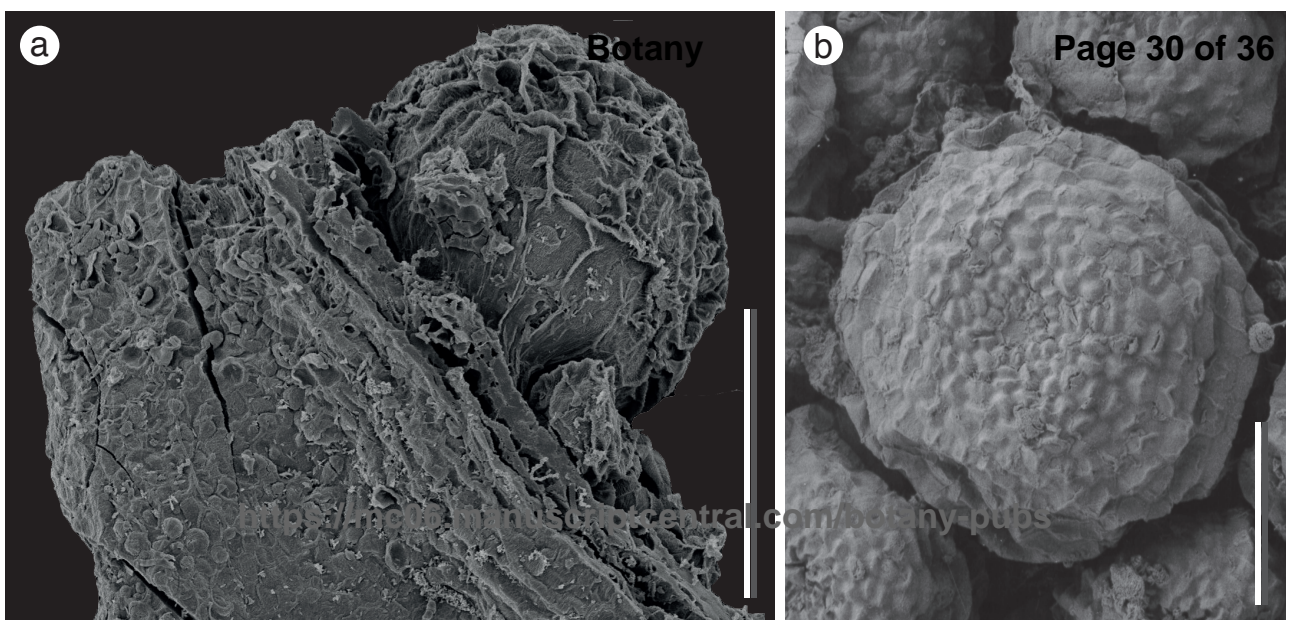



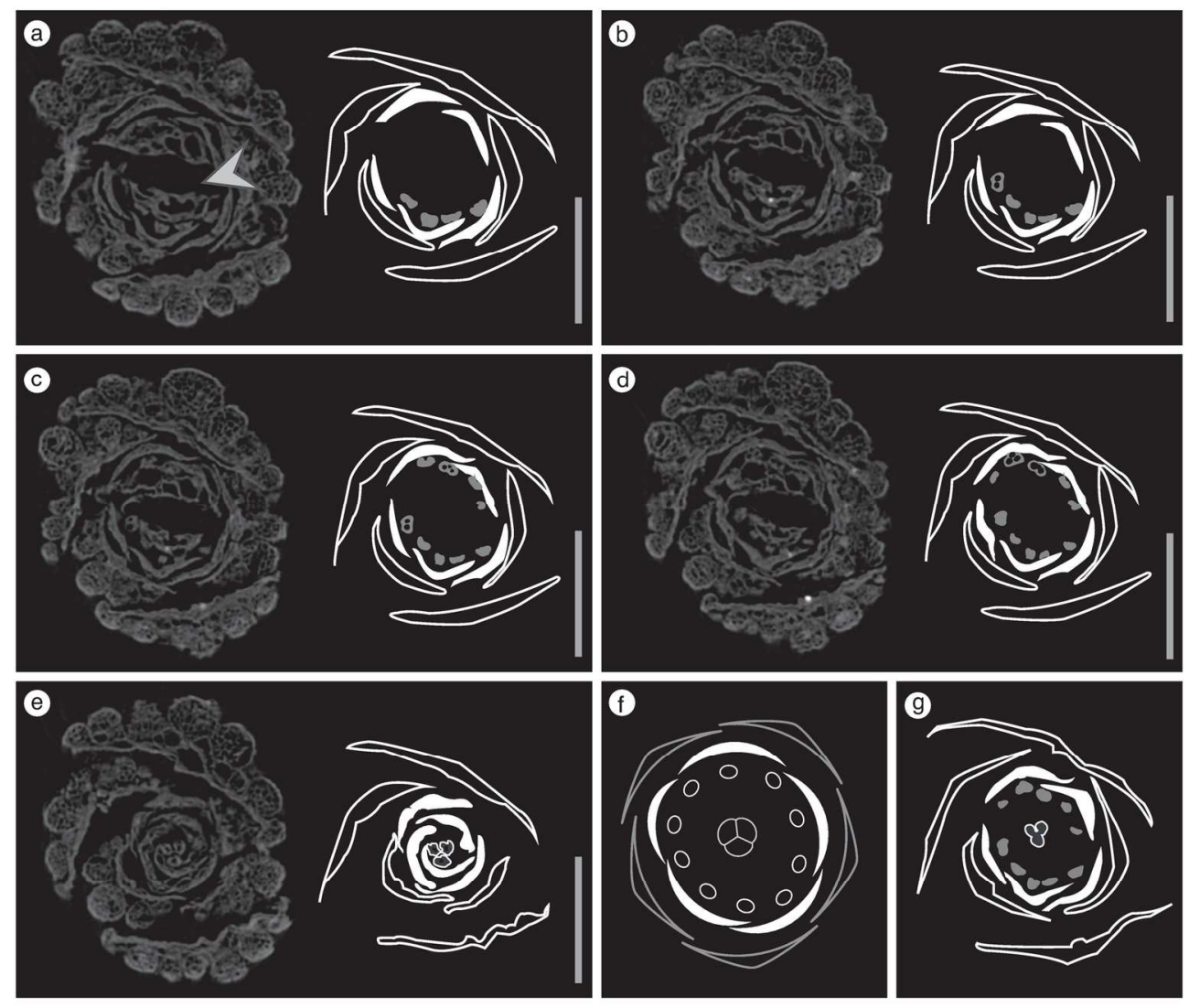

Fig. 4_Ct scan B\&W

$154 \times 130 \mathrm{~mm}(300 \times 300 \mathrm{DPI})$ 


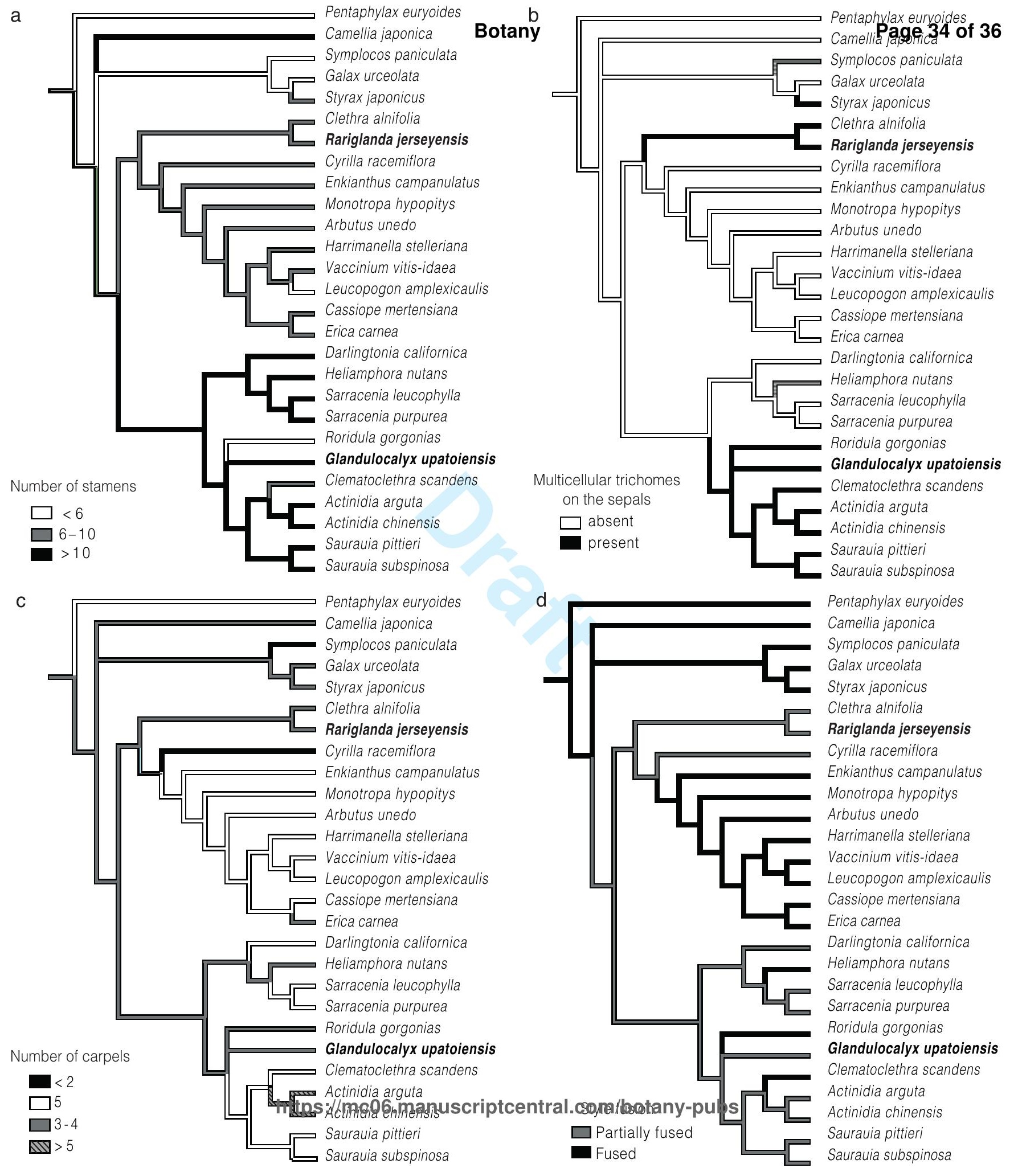




\section{Appendix}

\section{Appendix A1}

Appendix A1. Morphological matrix of extant Ericales and the fossils Rariglanda jerseyensis and Glandulocalyx upatoiensis

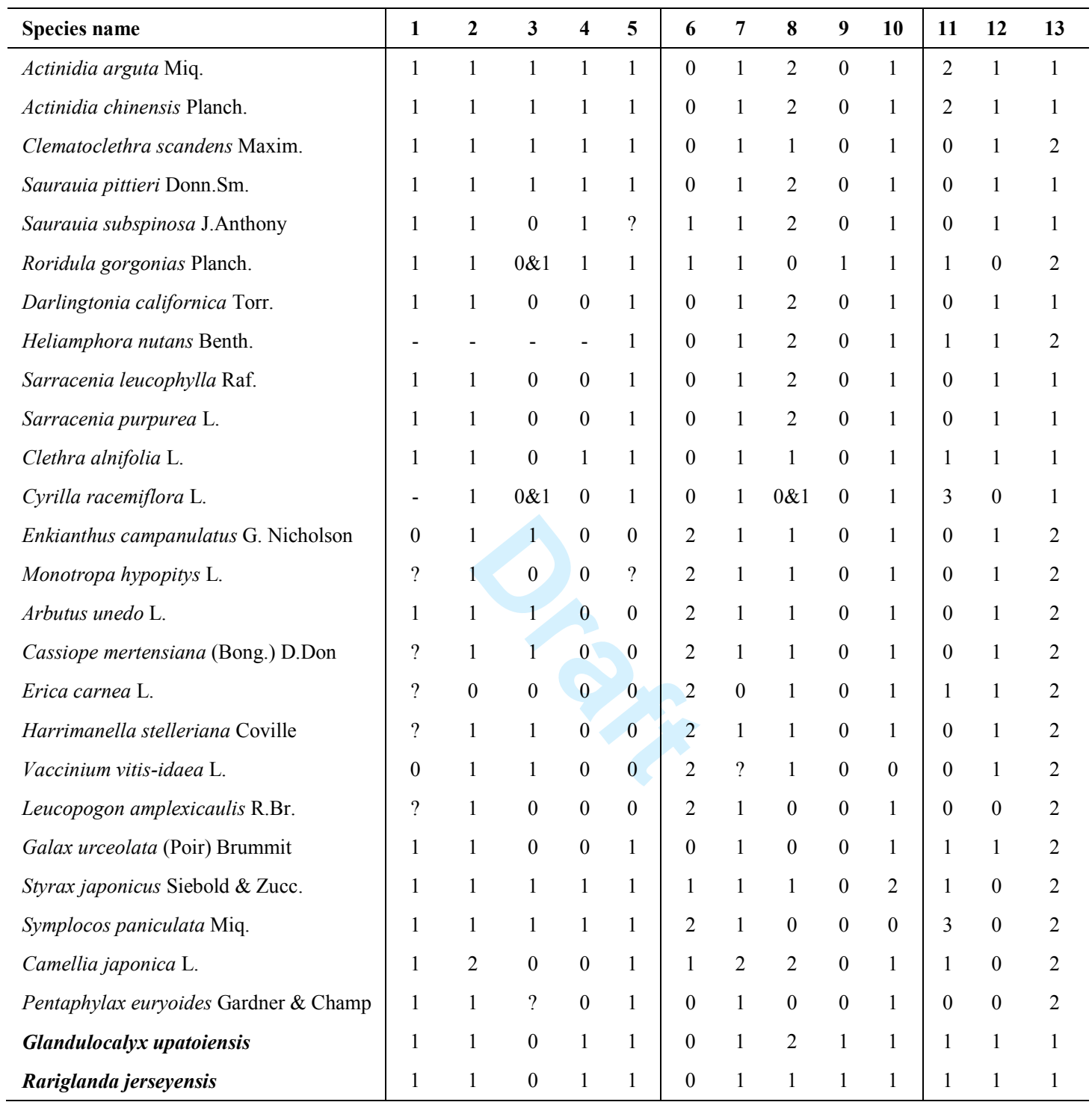




\section{Appendix $A 2$}

List of characters included in the matrix

1. Calyx aestivation: valvate $=0 ;$ imbricate $=1$

2. Number of sepals: $<5=0 ; 5=1 ;>5=2$

3. Calyx connation: free $=0$; partially connate $=1$; connate $=2$

4. Multicellular trichomes on the sepals: absent $=0$; present $=1$

5. Corolla aestivation: valvate $=0 ;$ imbricate $=1$

6. Corolla connation: free $=0$; partially connate $=1$; connate $=2$

7. Petal number: $<5=0 ; 5=1 ;>5=2$

8. Number of stamens: $<6=0 ; 6-10=1 ;>10=2$

9. Anther apical protrusion: absent $=0 ;$ present $=1$

10. Ovary position: inferior $=0$; superior $=1$; half-inferior $=2$

11. Carpel number: $5=0 ; 3-4=1 ;>5=2 ;<2=3$

12. Number of ovules: $<6=0$; numerous $=1$

13. Style fusion: free $=0$; partially fused $=1$; fused $=2$ 